\title{
MIKROFLORA JAMUR PRODUK KAKAO KERING SERTA KEMUNGKINAN PENGHAMBATAN JAMUR PENGHASIL TOKSIN OLEH BAKTERI ASAM LAKTAT DAN BACILLUS SPP.
}

\author{
Oleh : \\ Anton Rahmadi ${ }^{*}$
}

\begin{abstract}
Mycotoxins contamination in sun dried cocoa has become a concern in public health but it has not been studied thoroughly yet. This research aimed to understand the ecology of fungal contamination in relation to the occurrence of toxigenic metabolites in Indonesian and Australian fermented cocoa. The beans were surface disinfected with $0.4 \%$ chlorine prior to deposite onto Dichloran $18 \%$ Glycerol Agar (DG-18, OXOID). Total fungal count was obtained from serial dilutions on DG-18 medium. Streaking onto Dichloran Rose Bengal Chloramphenicol Agar (DRBC, OXOID) purified a specific mould colony. Simultaneously, Aspergillus sec. Flavi colonies were confirmed using Aspergillus Flavus Parasiticus Agar (AFPA, OXOID). The confirmatory test was mainly based on morphological examination under phase contrast microscope. Fungal population in Indonesian beans varied between $10^{4}-10^{5}$ $\mathrm{cfu} / \mathrm{g}$, while the populations on Queensland beans were consistently low $<100$ $-2.5 \times 10^{2} \mathrm{cfu} / \mathrm{g}$ ). However, there was a high incidence of potentially mycotoxigenic filamentous fungi on all bean samples. The main species were Aspergillus flavus, Aspergillus niger, Aspergillus wentii, Aspergillus clavatus, Penicillium citrinum, and Penicillium spinolosum. The beans from Queensland gave high counts of Bacillus species and lactic acid bacteria and it is suggested that they served as natural biocoritrol agents against the filamentous fungi.
\end{abstract}

Keywords : mycotoxigenic fungi, cocoa beans, lactic acid bacteria, Bacillus, natural biocontrol

\section{PENDAHULUAN}

roduksi kakao kering secara global mengalami peningkatan tahunan $6-10 \%$ sejak kurun 2001/2002 hingga 2005/2006 (ICCO, 2007). Saat ini, pasar kakao dunia berada pada kisaran 3,6 juta metrik ton dengan kontribusi Indonesia sebesar 13\% dari total produksi (ICCO, 2007; UNCTAD, 2007a). Persentase tersebut menempatkan Indonesia sebagai produsen terbesar ketiga di dunia. Dalam perdagangan kakao, kualitas biji coklat ditentukan salah satunya dengan kandungan jamur, dimana $3 \%$ adalah batas maksimal yang diperkenankan untuk grade I, dan maksimal $4 \%$ untuk grade II (Minifie, 1980). Standar perdagangan ini tidak berubah selama 25 tahun (Minifie, 1999; UNCTAD, 2007b). Lebih lanjut, CODEX Alimentarius $(2001 \mathrm{a}, \mathrm{b}, \mathrm{c})$ merilis tiga revisi atas standar perdagangan coklat, tetapi tidak menyentuh aspek kontaminasi jamur penghasil toksin ataupun metabolitnya.

*) Jurisan Teknologi Hassi Pentanian. 
Dalam berbagai penelitan (Galvez et al, 2006; Jespersen et al, 2005; Schwan dan Wheals, 2004; Ardhana dan Fleet, 2003; Schwan et al, 1997) proses yang kompleks terjadi selama fermentasi biji coklat, sehingga dimungkinkan tumbuhnya mikroorganisme yang tidak diinginkan seperti jamur penghasil toksin (Minifie, 1999). Kakao merupakan biji buah dari pohon coklat, Theobroma cacao, yang tumbuh baik di daerah tropis seperti Indonesia, Amerika Latin dan Afrika (Ardhana dan Fleet, 2003; Schwan dan Wheals, 2004; Nielsen et al, 2006). Polong dan pulp yang menutupinya dikeluarkan dari buah dan dijemur di atas pastik terpal, boks, ataupun papan. Pada saat penjemuran, proses fermentasi terjadi secara spontan, melibatkan mikroorganisme dalam spektrum yang luas dan saling suksesif.

Ardhana dan Fleet (2003) membagi proses fermentasi ini ke dalam dua kelompok besar, tahap awal (0-48 jam) dan tahap lanjut (48-120 jam). Pada tahap awal, beberapa jamur ditemukan tumbuh yaitu Aspergillus versicolor, A. Wentii, Penicillium citrinum, $P$. purpogenum, dan $P$. ochrocihoron. Kamir-kamir ini bertahan pada konsentrasi antara $10^{2}$ $10^{3} \mathrm{CFU} / \mathrm{g}$ yang kemudian menurun hingga tidak terdeteksi (< $100 \mathrm{cfu} / \mathrm{g}$ ) setelah $36 \mathrm{jam}$. Pada tahap lanjut, tidak dilaporkan adanya pertumbuhan jamur hingga proses fermentasi selesai. Selama proses pengeringan, aktifitas mikroorganisme masih terus berlangsung hingga membentuk karakter aroma, tekstur, dan warna yang spesifik (Ardhana dan Fleet. 2003; Nielsen et al, 2006).

Seperti yang dikemukanan Minifie (1980), jamur tumbuh di produk biji kakao dan menurut Pitt dan Hocking (1997) hampir semua fungi memproduksi toksin, yang disebut mikotoksin. ICMSF (2005) melaporkan kemungkinan adanya Aflatoksin dan Okratoksin di produk kakao, coklat, kacang-kacangan, dan sereal. Studi lanjut yang mengkonfirmasi pernyataan ini dilakukan di Italia (Tafuri et al, 2004) sekaligus merupakan satu-satunya publikasi keberadaan Okratoksin A di produk kakao, sementara Batista et al (2003) melaporkan hal yang sama untuk produk kopi.

Proses kontaminasi jamur dari produk kering kakao dimungkinkan karena pengeringan tidak sempurna, dalam hal ini Minifie (1999) memberikan titik kritis pada level $8 \%$ kadar air dan rekomendasi $6-7 \%$.

Makalah ini merupakan bagian dari penelitian untuk mempelajari proses kontaminasi jamur dan mikotoksinnya, sehingga diharapkan dapat menghasilkan kakao dengan kualitas yang lebih baik. Secara khusus, makalah ini menampilkan hasil isolasi, identifikasi dan enumerasi jamur-jamur potensial penghasil toksin yang tumbuh pada biji cokelat asal Indonesia, Queensland, Australia dan Kepulauan Solomon. Selain itu, penelitian ini juga mendokumentasikan total plate count, bakteri asam laktat, dan Bacillus spp dalam upaya mencari latar belakang mikrobiologis pada sampel-sampel yang kontaminasi jamurnya sangat rendah.

\section{METODE}

\section{Sampel Kakao}

Biji kakao kering diperoleh dengan bantuan Dinas Perkebunan Propinsi Kalimantan Timur untuk tiga wilayah, Samarinda, Penajam (bagian selatan Kaltim), dan Malinau (bagian utara Kaltim), sedangkan untuk wilayah Sulawesi, Irian Jaya dan Solomon Islands menggunakan stok tahun 2005 yang tersedia di University of New South Wales. Sampel asal Queensland diperoleh dari Mr. Hugh Dirck, PhD student, yang meneliti tentang fermentasi Kakao dari University of New South Wales, Australia. Sampel dipaket dalam kantung plastik dan disimpan pada suhu dan kelembaban ruangan, dijauhkan dari cahaya matahari langsung sebelum dianalisa.

\section{Media}

Media yang digunakan adalah Dichloran Rose Bengal Chloramphenicol Agar (DRBC, Oxoid), Aspergillus Flavus Parasiticus Agar (AFPA, Oxoid) dan Dichloran 18\% Glycerol Agar (DG-18, Oxoid). Semua media ditambahkan suplemen Chloramphenicol $100 \mathrm{mg} / \mathrm{L}$. Dua metode sampling digunakan untuk memperoleh spektrum fungi yang lebih luas. 


\section{Inokulasi langsung}

Batista et al (2003) merekomendasikan 30 biji kakao, 15 diantaranya mendapat perlakuan disinfeksi permukaan dengan perendaman pada $1 \%$ asam hidroklorida selama 2 menit, untuk kemudian diletakkan secara aseptik di atas medium agar DG-18.

\section{Inokulasi dengan pengenceran}

Sebanyak $10 \mathrm{~g}$ biji kakao ditimbang secara aseptis dan direndam selama 30 menit pada $0,1 \%$ peptone water (Oxoid) di dalam stomacher. Setelah direndam, sampel dihancurkan menggunakan stomacher 400 sesuai Pitt dan Hocking (1997) selama 3 menit. Proses pengenceran berseri (1:9) menggunakan peptone water dilakukan sampai $10^{.5}$ untuk sampel Samarinda, Penajam, dan $10^{-3}$ untuk sampel-sampel yang lain. Setelah proses homogenisasi menggunakan vortex, sebanyak $0,1 \mathrm{~mL}$ sampel dari 3 pengenceran terakhir di inokulasikan di atas medium DG-18 dengan teknik spread plating sesuai rekomendasi Pitt dan Hocking (1997).

\section{Pengamatan Koloni Jamur}

Koloni jamur (kapang dan kamir) yang tumbuh pada inokulasi langsung dan inokulasi dengan pengenceran dihitung setelah inkubasi dalam kondisi aerobik pada suhu $25{ }^{\circ} \mathrm{C}$ selama 1-4 hari. Untuk inokulasi dengan pengenceran, dihitung frekuensi terdapatnya pada setiap sampel, sementara untuk inokulasi dengan pengenceran dihitung pembentukan koloni pada masing-masing pengenceran.

Koloni-koloni yang berbeda diamati bentuk morfologinya dan diamati di bawah mikroskop. Tiga representasi sampel yang sejenis diisolasi dan dipurifikasi pada medium DRBC menurut metode Ardhana dan Fleet (2003).

\section{Identifikasi jamur}

Proses identifikasi terhadap semua koloni yang berhasil diisolasi dari inokulasi langsung dilakukan di laboratorium Mikrobiologi, Departemen IImu Pangan, University of New South Wales, Sydney. Pengamatan melingkupi observasi morfologi aseksual dan seksual di bawah mikroskop fase kontras untuk mengkarakterisasi jamur-jamur. Proses konfirmasi koloni tipikal dari Aspergillus flavus dan A. parasiticus dilakukan menggunakan medium AFPA (Pitt dan Hocking, 1997). Konfirmasi hasil identifikasi jamur dilakukan bersama Dr. A.D. Hocking (CSIRO, North Ryde Australia).

\section{Perhitungan dan identifikasi bakteri asam laktat (BAL) serta Bacillus spp.}

Sebanyak $10 \mathrm{~g}$ sampel ditimbang secara aseptis dan dicampurkan dengan $90 \mathrm{~mL}$ larutan peptone $0,1 \%$ steril (Oxoid, Melbourne) di dalam kantung Stomacher. Sampelsampel dimaserasi di dalam Stomacher 400 selama 3 menit, diikuti dengan pengguncangan dan pemijatan kuat selama 3 menit untuk menghasilkan homogenat yang seragam. Pengenceran berseri dilakukan dalam tabung-tabung berisi $0,1 \%$ larutan peptone steril. Masing-masing larutan ini dicampurkan dan diaduk didalam vortex mixer sebelum dipindahkan secara spread plating di atas medium yang ditentukan. Sebanyak $0,1 \mathrm{~mL}$ alikuot dari masing-masing pengenceran yang diinginkan diinokulasikan duplo ke atas media Standard Plate Count Agar (Accumedia, Michigan), de Mann Rogose Sharpe Agar (Oxoid, Basingstoke), dan Bacillus cereus Agar (Oxoid, Basingstoke). Parameter tingkat pengenceran, waktu dan suhu inkubasi dideskripsikan pada Tabel 1. Bakteribakteri yang berhasil diisolasi lalu diisolasi dan dipurifikasi pada medium yang sesuai.

\section{Konfirmasi koloni bakteri asam laktat dan Bacillus spp.}

Satu loop dari biomassa bakteri yang akan diidentifikasi diletakkan di atas kaca preparat dan diamati di bawah mikroskop fase kontras (Nikon, Japan) pada pembesaran 1000 kali. Semua koloni yang dicurigai sebagai bakteri asam laktat dan Bacillus spp diamati bentuk koloni, pewarnaan Gram, dan keberadaan endospora yang kemudian dicatat untuk dibandingkan dengan referensi. Tes katalase dilakukan untuk koloni yang 
dicurigai sebagai bakteri asam laktat dengan meneteskan $\mathrm{H}_{2} \mathrm{O}_{2}$ di atas kaca preparat yang berisi koloni terduga bakteri asa:n laktat.

\section{HASIL DAN PEMBAHASAN \\ Persebaran spesies jamur}

ICMSF (2005) menyebutkan empat kategori jamur yang mengkontaminasi produk pangan, field fungi, storage fungi, contaminant fungi, dan invasive fungi. Jamur yang ditemukan pada saat proses pemanenan disebut field fungi, sementara pada proses penyimpanan, storage fungi. Invasive fungi adalah apabila jamur mampu menyerang biji dan disebut contaminat fungi ji.ka mengkontaminasi pada saat proses pengolahan.

Sebagaian besar isolat ini diperoleh dari hasil direct plating. Dari 15 sampel, mikroflora kakao kering didominasi oleh Aspergillus niger diikuti dengan A. flavus dengan persebaran keduanya antara $0-60 \%$ dari populasi jamur. Tabel 2. memberikan ilustrasi beberapa jamur yang umum ditemukan pada tanaman, misalnya Chaetosporium globosum, Cladosporium, sp., Mucor pyriformis, dan Stemphylium sp. P. citrinum dan P. spinolosum merupakan dua spesies dari genus Penicillium yang paling sering ditemukan. Diantara grup Penicillium yang cukup unik adalah ditemukannya Eupenicillium cinnamopurporeum yang dengan mudah diidentifikasi dari kombinasi bentuk dan warna merah muda kecoklatannya pada medium MEA.

\section{Perhitungan total jamur}

Umumnya, proses pengenceran dilakukan dengan menambahkan $90 \mathrm{~mL}$ larutan pengencer pada $10 \mathrm{~g}$ sampel (1:9), untuk kemudian dihancurkan menggunakan stomacher (Bankole et al, 2005). Untuk memungkinkan pengenceran sangat rendah ( $1: 2$ atau 1:3), maka sampel harus ditumbuk terlebih dahulu secara aseptis, untuk kemudian ditimbang dan ditambahkan pengencer. Sebaliknya, apabila menggunakan stomacher, hasil pengenceran yang diperoleh tidak sebaik penumbukan sampel sebelum penambahan larutan pengencer. Menurut Pitt dan Hocking (1997) proses plating harus dilakukan secepatnya dikarenakan spora jamur yang mudah mengendap, sehingga diperoleh hasil yang lebih rendah dari sebenarnya. Untuk itu, dalam dillution plating, Hocking et al (1997) merekomendasikan waktu kurang dari 1 menit setelah tabung berisi sampel dikocok menggunakan vortex mixer.

Sampel kakao yang berasal dari Kalimantan Timur memiliki total jamur yang sangat tinggi bila dibandingkan dengan sampel-sampel lainnya. Sampel-sampel yang berasal dari Queensland umumnya ditumbuhi jamur dalam jumlah sedikit hingga tidak terdeteksi dengan menggunakan metode dillution plating.

\section{Peluang penghambatan pertumbuhan jamur oleh Bakteri Asam Laktat dan Bacillus spp.}

Dalam genus Bacillus yang dideteksi umumnya terdiri dari beberapa spesies, namun tidak dilakukan identifikasi lebih lanjut hingga taraf spesies. Uji konfirmasi sederhana meliputi pewarnaan gram, pengamatan di bawah mikroskop untuk melihat ada atau tidaknya endospora. Berikutnya, beberapa isolat Bacillus spp. yang didapat diuj tumbuhkan pada medium PEMBA untuk melihat kemampuan mereduksi mannitol dan memproduksi zona berwarna kuning disekitar koloni. Begitu pula dengan bakteri asam laktat yang berhasil diisolasi hanya melaui konfirmasi pewarnaan gram, uji negatif katalase, dan morfologi dibawah mikroskop fase kontras. Pengujian selanjutnya adalah dengan menumbuhkan beberapa isolat BAL yang diperoleh pada medium MRS agar.

Dari tabel 4., semua sampel yang berasal dari Indonesia dan kepulauan Solomon, diperoleh jumlah bakteri asam laktat hanya berkisar 3 hingga 5 skala eksponensial cfu/g, tetapi memiliki populasi Bacillus spp. yang tinggi (8-9 skala eksponensial cfu/g). Sampel yang berasal dari Queensland memiliki total mikroba yang tinggi, didominasi oleh genus Bacillus dan bakteri penghasil asam laktat. 
Dalam penelitian lain, genus Leuconostoc, Pediococcus, Lactococcus, dan Lactobacillus adalah yang bakteri asam laktat yang paling umum diisolasi dari biji cokelat terfermentasi (Camu et al., 2007). Ardhana dan Fleet (2003) juga melaporkan keberadaan Lactobacillus plantarum dan L. hilgardii yang mampu bertahan hidup hingga akhir proses fermentasi, serta kemungkinan besar tetap hidup selama proses penyimpanan biji cokelat.

Diantara semua bakteri pembentuk spora yang terdapat pada biji cokelat, spesies dari Bacillus adalah mikroflora yang dominan setelah fermentasi cokelat berlangsung selama 72 jam. Spesies-spesies yang signifikan adalah B. pumillus, B. licheniformis, B. substilis and B. cereus (Ardhana dan Fleet, 2003). Bakteri-bakteri ini mampu bertahan pada konsentrasi $10^{4}-10^{6} \mathrm{cfu} / \mathrm{g}$ (Ardhana dan Fleet, 2003) dan sporanya tetap bertahan setelah pengeringan dan penyangraian (Schwan dan Wheals, 2004).

Dalam Tabel 4, didapatkan temuan bahwa bakteri asam laktat dan Bacillus spp terdapat dalam jumlah yang cukup tinggi. Apabila data ini dikolaborasikan dengan hasil yang diperoleh pada Tabel 3., maka dapat dideduksi bahwa kombinasi bakteri asam laktat dan Bacillus spp yang terdapat dalam biji coklat mampu menghambat pertumbuhan jamur berpotensi menghasilkan mikotoksin seperti Aspergillus flavus, A niger. A carbonarius, dan dari genus Penicillium. Efek penghambatan ini dapat dilihat dalam Gambar 1 yang mewakili beberapa sampel biji cokelat yang tidak ditumbuhi oleh jamur, melainkan terdapat cairan menyerupai lendir (slime) yang merupakan eksopolisakarida yang diproduksi oleh Bacillus spp.

Aflatoksin dan mikotoksin lainnya dapat didegradasi secara fisik, kimiawi, ataupun biologis (Park, 1993). Pendekatan fisik meliputi pemanasan, penggunaan sinar ultra violet, atau radiasi menggunakan ion. Akan tetapi, sejauh ini upaya pengurangan aflatoksin secara fisik dianggap tidak efektif. Penggunaan klorin, senyawa pengoksidasi dan senyawa yang mampu menghidrolisis mikotoksin memerlukan proses perlakuan yang mahal dan sangat memungkinkan hilangnya komponen nutrisi lainnya. Dalam metode biologis Marth and Doyle (1979) melaporkan bahwa banyak mikroorganisme termasuk bakteri, kapang, kamir mampu menyerap sebagian kecil dari Aflatoksin dari bahan pangan. Akan tetapi, penanganan secara biologis ini belum memiliki metode praktis untuk dapat digunakan.

Berkenaan dengan keberadaan bakteri asam laktat, Line dan Brackett (1995) menyebutkan beberapa strain dari Lactobacillus, selain berkemampuan menghambat biosintesis pembentukan mikotoksin, juga mampu mengikat mikotoksin pada dinding selnya hingga $60 \%$ dari konsentrasi mikotoksin yang diberikan pada medium bufer fosfat (PBS) (Shetty dan Jespersen, 2006; Gourama, 1997). Konsentrasi optimum bakteri asam laktat yang mampu digunakan untuk mengikat mikotoksin secara efektif berkisar $10^{9}$ cfu/mL (Fuchs et al, 2008; Shetty dan Jespersen, 2006; El Nezami et al, 1998). Hasil yang diperoleh pada Tabel 3., pada sampel-sampel yang berasal dari Queensland, didapatkan konsentrasi bakteri asam laktat berkisar pada $10^{8}-10^{9} \mathrm{cfu} / \mathrm{g}$.

Faktor-faktor yang menentukan kemampuan penyerapan mikotoksin oleh bakteri asam laktat adalah: (1) nilai $\mathrm{pH}$, dimana semakin rendah $\mathrm{pH}$ semakin efektif penyerapan dilakukan, (2) konsentrasi BAL, dimana semakin tinggi konsentrasi semakin efektif penyerapan dilakukan, (3) strain BAL, beberapa galur bakteri asam laktat seperti $L$. plantarum, L. acidophilus, L. rhamnosus, L. bulgaricus memiliki kemampuan pengikatan hingga lebih dari $60 \%$ (4) konsentrasi awal mikotoksin, dimana pada cemaran $5 \mathrm{ppb}$ hampir semua mikotoksin mampu diserap oleh bakteri asam laktat, (6) kadar substrat penghambat proses pengikatan seperti urea, dimana semakin sedikit konsentrasi substrat penghambat semakin tinggi peluang pengikatan mikotoksin. (Simanjuntak, 2008; Fuchs et al, 2008; Shetty dan Jespersen, 2006; El Nezami et al, 1998; Gourama, 1997).

\section{KESIMPULAN}

A. flavus, A. niger, A. wentii, $P$. citrinum, dan P. spinolosum adalah jamur-jamur yang paling dominan terdapat dalam biji cokelat kering fermentasi serta berpotensi menghasilkan mikotoksin. Terdapat konsentrasi Bakteri Asam Laktat dan Bacillus dalam 
konsentrasi yang amat tinggi $\left(10^{8}-10^{10} \mathrm{cfu} / \mathrm{g}\right)$ pada beberapa sampel yang total jamurnya rendah $(<100 \mathrm{cfu} / \mathrm{g}$ ). Pertumbuhan jamur-jamur berpotensi menghasilkan mikotoksin kemungkinan dihambat oleh kombinasi Bakteri Asam Laktat dan Bacillus pada sampelsampel yang total jamurnya rendah tersebut.

\section{UCAPAN TERIMA KASIH}

Terima kasih penulis haturkan kepada Pemerintah Indonesia, c.q. Dirjen Dikti, Pemerintah Australia, dan Dept. Food Science UNSW, Sydney.

\section{DAFTAR PUSTAKA}

Ardhana, M.M. dan G.H. Fleet. 2003. The microbial ecology of cocoa bean fermentations in Indonesia. International J. Food Microbiology, 86: 87-99.

Bankole, S.A., B.M. Ogunsowo, dan D.A. Eseigbe. 2005. Aflatoxins in Nigerian dryroasted groundnuts. Food Chemistry 89: 503-506.

Batista, L.R., S.M. Chalfoun, G. Prado, R.F. Schwan, dan A.E. Wheals. 2003. Toxigenic fungi with processed (green) coffee beans (Coffee arabica L.). International J. Food Microbiology, 85(3): 293-300.

CODEX. 2001a. Standard for Cocoa Butter. Codex Alimentarius. [online at] http://www.codexalimentarius.net/download/standards/66/CXS_086e.pdf [date access] 1 Oktober 2007.

CODEX. 2001b. Standard for Cocoa powders (cocoas) and dry mixtures of cocoa and sugars. Codex Alimentarius. [online at] http://www.codexalimentarius.net/download/standards/68/CXS_105e.pdf [date access] 1 Oktober 2007.

CODEX. 2001c. Standard for Cocoa (Cacao) Mass (Cocoa/Chocolate Loquor) and Cocoa Cake. Codex Alimentarius. [online at] http://www.codexalimentarius.net/download/standards/69/CXS_141e.pdf [date access] 1 Oktober 2007.

Camu, N., T.D. Winter, K. Verbrugghe, I. Cleenwerck, P. Vandamme, J.S. Takrama, M. Vacanneyt, dan L.D. Vuyst. 2007. Dynamics and biodiversity of populations of lactic acid bacteria and acetic acid bacteria involved in spontaneous heap femerntation of cocoa beans in Ghana. Applied and Environmental Microbiology, 73(6): 1809-1824.

El-Nezami, H, P. Kankaanpaa, S. Salminen dan J. Ahokas. 1998. Ability of Dairy Strains of Lactic Acid Bacteria to Bind a Common Food Carcinogen, Aflatoxin B1. Food and Chemical Toxicology 36: 321-326

Fuchs S., G. Sontag, R. Stidl, V. Ehrlich, M. Kundi, dan S. Knasmueller. 2008. Detoxification of patulin and ochratoxin A, two abundant mycotoxins, by lactic acid bacteria. Food and Chemical Toxicology 46: 1398-1407

Galvez, S.L., G. Loiseau, J.L. Paredes, M. Barel, dan J.-P. Guiraud. 2007. Study on microflora and biochemistry of cocoa fermentation in the Dominican Republic. International J. Food Microbiology, 114: 124-130.

Gourama, H. 1997. Inhibition of Growth and Mycotoxin Production of Penicillium by Lactobacillus Species. Lebensm.-Wiss. u.-Technol., 30; 279-283.

Hocking, A.D., G. Arnold, I. Jenson, K. Newton, dan P. Sutherland, 1997. Foodborne Microorganisms of Public Health Significance, 5th ed. AIFST (NSW Branch) Food Microbiology Group., Australia. 
ICCO. 2007. Annual Report. 2005/2006 ed. The International Cocoa Organization, London, UK.

ICMSF. 2005. Microbial Ecology of Food Commodities 2nd ed. Microorganisms in Food, ed. 6. Chapman \& Hall.

Jespersen, L., D.S. Nielsen, S. Henholt, dan M. Jakobsen. 2005. Occurrence and diversity of yeasts involved in fermentation of West African cocoa beans. FEMS Yeast Research, 5: 441-453.

Line J. E., R.E. Brackett. 1995. Factors affecting aflatoxin B1 removal by Flavobacterium aurantiacum. Journal of Food Protection 58: 91-94.

Marth E. H. dan M.P. Doyle. 1979. Update on molds: degradation of aflatoxin. Food Technology January, 81-87.

Minifie, B.W. 1980. Chocolate, cocoa, and confectionery, ed. 2nd. AVI Publishing, Connecticut

Minifie, B.W. 1999. Chocolate, cocoa, and confectionery, ed. 3rd. AVI Publishing. Connecticut

Nielsen, D.S., O.D. Teniola, L. Ban-Koffi, M. Owusu, T.S. Andersson, dan W.H. Holzapfel. 2006. The microbiology of Ghanaian cocoa fermentations analysed using culturedependent and culture-independent methods. International Journal of Food Microbiology, (article in press).

Park D. C. 1993. Controlling aflatoxin in food and feed. Food Technology October, 92-96.

Pitt, J.I. dan A.D. Hocking. 1997. Fungi and Food Spoilage. 2nd ed. Blackie Academic \& International, Australia

Schwan, R.F. and A.E. Wheals, 2004. The microbiology of cocoa fermentation and its role in chocolate quality. Critical Review in Food Science and Nutrition, 44(4): 205-221.

Schwan, R.F., R.M. Cooper, dan A.E. Wheals. 1997. Endopolygalacturonase secretion by Kluyveromyces marxianus and other cocoa pulp-degrading yeasts. Enzyme and Microbiol Technology, 21: 234-244.

Simanjuntak, R. 2008, Isolasi dan Karakterisasi Bakteri Asam Laktat dari Air Rendaman Kedelai untuk Pengikatan Aflatoksin B1. Prosiding Seminar PATPI 14-16 Oktober 2008, Palembang, kode makalah: MKP-16, dalam proses cetak.

Shetty, P. H. dan L. Jespersen. 2006. Saccharomyces cerevisiae and lactic acid bacteria as potential mycotoxins decontaminating agents. Trends in Food Science \& Technology 17: 48-55

Tafuri, A., R. Ferracane, dan A. Ritieni. 2004. Ochratoxin A in Italian marketed cocoa products. Food Chemistry, 88: 487-494.

UNCTAD. 2007a. Production, Cocoa Market. United Nations Conference on Trade and Development. [online at] http://www.unctad.org/infocomm/anglais/cocoa/market.htm [date access] 6 Oktober 2007.

UNCTAD. 2007b. Cocoa Quality. United Nations Conference on Trade and Development. [online at] http://www.unctad.org/infocomm/anglais/cocoa/quality.htm [date access] 4 Oktober 2007 


\section{LAMPIRAN}

Tabel 1. Parameter tingkat pengenceran, waktu dan suhu inkubasi untuk perhitungan total bakteri pada biji cokelat

\begin{tabular}{llccc}
\hline \multirow{2}{*}{ Jenis pengamatan } & Media & $\begin{array}{c}\text { Pengenceran } \\
\text { diperlukan }\end{array}$ & \begin{tabular}{c} 
Inkubasi \\
\cline { 3 - 5 }$\left({ }^{\circ} \mathrm{C}\right)$
\end{tabular} & $\begin{array}{c}\text { Waktu } \\
\text { (hari) }\end{array}$ \\
\hline Bacillus species & PEMBA & $10^{-5}, 10^{-6}, 10^{-7}, 10^{-8}$ & 37 & 1 \\
Total bakteri & SPC & $10^{-6}, 10^{-7}, 10^{-8}, 10^{-9}$ & 37 & 2 \\
Bakteri asam laktat & MRS & $10^{-5}, 10^{-6}, 10^{-7}$ & 37 & 2 \\
\hline
\end{tabular}

Tabel 2. Persebaran spesies jamur

\begin{tabular}{lc}
\hline Spesies & Sampel positif \\
\hline Aspergillus flavus & 15 \\
Aspergillus niger & 15 \\
Aspergillus carbonarius & 2 \\
Aspergillus clavatus & 3 \\
Aspergillus wentii & 2 \\
Chaetosporium globosum & 2 \\
Cladosporium sp & 1 \\
Mucor pyriformis & 3 \\
Stemphylium sp & 2 \\
P. spinolosum & 4 \\
P. citrinum & 15 \\
Fusarium spp. & 6 \\
Eurotium sp. & 6 \\
Eupenicillium cinnamopurporeum & 1 \\
\hline
\end{tabular}

Tabel 3. Perhitungan Total Jamur

\begin{tabular}{lrr}
\hline Sampel & DRBC (cfu/g) & DG-18 (cfu/g) \\
\hline Malinau, East Kalimantan & 23.000 & 38.000 \\
Solomon Islands & 170 & 110 \\
Penajam, East Kalimantan & 7.200 .000 & 2.100 .000 \\
Samarinda, East Kalimantan & 200.000 & 200.000 \\
Sulawesi & 220 & $<100$ \\
Irian Jaya & $<100$ & $<100$ \\
Box Sundried Queensland & $<100$ & $<100$ \\
Oven Control Queensland & $<100$ & $<100$ \\
Sundried Control Queensland & $<100$ & $<100$ \\
Tumbler Oven Queensland & $<100$ & $<100$ \\
Washed Queensland & $<100$ & $<100$ \\
Sundried Oven Queensland & $<100$ & 250 \\
Box Oven Queensland & $<100$ & $<100$ \\
Heap Sundried Queensland & $<100$ & $<100$ \\
Long Fermentation Queensland & $<100$ & 130 \\
\hline
\end{tabular}


Tabel 4. Perhitungan total koloni, bakteri asam laktat (BAL), dan Bacillus spp.

\begin{tabular}{lrrr}
\hline Sampel & \multicolumn{1}{c}{ TPC $^{3}$} & \multicolumn{1}{c}{ BAL $^{3}$} & Bacillus spp. $^{3}$ \\
\hline Malinau, East Kalimantan & $9-10$ & $3-5$ & $8-9$ \\
Solomon Islands & $10-11$ & $3-5$ & $8-9$ \\
Penajam, East Kalimantan & $9-10$ & $3-5$ & $8-9$ \\
Samarinda, East Kalimantan & $9-10$ & $3-5$ & $8-9$ \\
Sulawesi & $8-9$ & $3-5$ & $8-9$ \\
Irian Jaya & $9-10$ & $3-5$ & $8-9$ \\
Box Sundried Queensland & $9-10$ & $7-8$ & $8-9$ \\
Oven Control Queensland & $9-10$ & $8-9$ & $8-9$ \\
Sundried Control Queensland & $10-11$ & $8-9$ & $7-8$ \\
Tumbler Oven Queensland & $10-11$ & $8-9$ & $8-9$ \\
Washed Queensland & $9-10$ & $6-7$ & $8-9$ \\
Sundried Oven Queensland & $9-10$ & $7-8$ & $7-8$ \\
Box Oven Queensland & $9-10$ & $7-8$ & $8-9$ \\
Heap Sundried Queensland & $8-9$ & $7-8$ & $7-8$ \\
Long Fermentation Queensland & $10-11$ & $8-9$ & $8-9$ \\
\hline Kerangnis
\end{tabular}

Keterangan: a = skala eksponensial cfu/g

Gambar 1. Biji cokelat asal Queensland tanpa disinfeksi permukaan yang telah diinkubasi selama 6 hari pada suhu $25^{\circ} \mathrm{C}$ di atas medium DG- 18 . 